Int. J. Dev. Biol. 52: 9-20 (2008)

doi: $10.1387 /$ ijdb.072304al

\title{
PBX proteins: much more than Hox cofactors
}

\author{
AUDREY LAURENT, RÉJANE BIHAN, FRANCIS OMILLI, STÉPHANE DESCHAMPS and ISABELLE PELLERIN* \\ IGDR, UMR CNRS 6061, Génétique et Développement, IFR 140, Faculté de Médecine, Université de Rennes 1, France
}

\begin{abstract}
Pre-B cell leukaemia transcription factors (PBXs) were originally identified as Hox cofactors, acting within transcriptional regulation complexes to regulate genetic programs during development. Increasing amount of evidence revealed that PBX function is not restricted to a partnership with Hox or homeodomain proteins. Indeed, PBXs are expressed throughout murine embryonic development and are involved in several developmental pathways including Hoxindependent mechanisms. This review summarizes what is known about PBX partnerships and proposes to position PBXs as central developmental factors whose role consists of integrating transduction signals, in order to regulate gene expression programs during development.
\end{abstract}

KEY WORDS: PBX, Hox, homeodomain, cofactors

\section{Introduction}

PBX1 (pre-B-cell leukaemia transcription factor 1 ) was initially identified as a proto-oncogene in human leukaemia induced by the expression of the oncogenic fusion protein E2a-PBX1 (Kamps et al., 1990, Nourse et al., 1990). PBX1 is classified in a particular subclass of homeodomain proteins designated as the PBC family, referring to the conserved $\mathrm{PBC}$ motif at the $\mathrm{N}$-terminus of their homeodomain. This PBC subclass belongs to the TALE superfamily characterized by a Three-Amino-Acid Loop Extension within the homeodomain of these proteins. The PBC subclass comprises the proteins Pbx1, Pbx2, Pbx3 (Monica et al., 1991) and $\mathrm{Pbx} 4$ in mammals (Wagner et al., 2001), Lazarus or Lzr in zebrafish (Popperl et al., 2000, Waskiewicz et al., 2001), as well as Extradenticle (or Exd) in Drosophila and Ceh-20 in Caenorhabditis elegans (Shanmugam et al., 1999, Shen et al., 1999). It has been demonstrated that PBC proteins are able to interact with a subset of Hox proteins and, as such, were considered as essential Hox cofactors involved in developmental gene regulation (reviewed in Mann and Affolter, 1998, Moens and Selleri, 2006). Since then, PBC proteins have been investigated by studying their interactions with Hox proteins. However, an increasing amount of evidence revealed that $\mathrm{Pbx}$ function was not restricted to a partnership with Hox or homeodomain proteins. Indeed, Pbx interacting proteins were subsequently identified that are involved in cytoskeleton assembly and/or regulation (Huang et al., 2003). In a recent two-hybrid screen performed in our laboratory, only $6 \%$ of putative $\mathrm{Pbx} 1$ partners corresponded to homeodomain proteins and only $18 \%$ were transcription factors (Fig. 1). This increasing amount of non-homeodomain transcrip- tion factors among Pbx1 partners points out that $\mathrm{Pbx}$ proteins have a broader role during development than previously assigned as Hox cofactor. This review summarizes what is known about PBC partnerships, beginning with the well-known cooperation with Hox proteins and extending to newly identified partnerships. We propose to position Pbx proteins as central developmental factors whose role consists of integrating transduction signals by interacting with numerous proteins, in order to regulate gene expression programs during development.

\section{In the beginning, there were the Hox proteins}

Hox proteins make up a family of transcription factors that specify anteroposterior identities during development throughout the animal kingdom, being characterized by a very highly conserved DNA-binding motif termed the homeodomain. In mammalians, 39 Hox genes are classified in 13 paralog groups within four separate clusters (A, B, C and D). Although these proteins are able to trigger very specific developmental programs, they all bind in vitro to a TAAT core sequence occurring approximately once every 500 base pair within the genome (Galant et al., 2002). Indeed, attempts to identify in vivo target genes by Chromatin Immunoprecipitation (ChIP) experiments, showed that these proteins bind DNA in a widespread fashion on TAAT sequences (Carr and Biggin, 1999, Walter et al., 1994, Williams et al., 2005). To

Abbreviations used in this paper: ChIP, Chromatin ImmunoPrecipitation; HPIP, Haematopoietic Pbxl Interacting Protein; NR, Nuclear Receptor; PBX, Pre-B-cell leukaemia transcription factor1; RTK, Receptor Tyrosine Kinase; SR, Steroid Receptor; XPIP, X Pbx Interacting Protein.

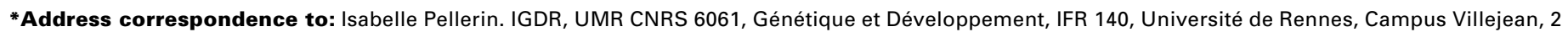
avenue du Professeur Léon Bernard, CS34317, F-35043 Rennes Cedex, France. Fax. +33-2-23-23-44-78. e-mail: isabelle.pellerin@univ-rennes1.fr
} 
explain this apparent paradox between the low DNA specificity of these proteins and their ability to trigger distinct developmental programs, it was suggested that the level of Hox proteins was more important than their nature, i.e., these proteins were so similar that they were interchangeable (Duboule, 2000). This theory or "quantitative model" is consistent with some elegant gene-swapping experiments showing a total functional equivalence between Hoxa3 and Hoxd3 in mouse, in which the coding sequences of the two paralog genes were exchanged (Greer et al., 2000). While this functional equivalence highlights the crucial role of quantitative modulation in Hoxgene expression, other data clearly demonstrate that the biochemical properties of Hox proteins participate in their function. As an example, mice in which the Hoxa11homeobox has been substituted by the Hoxa13homeobox exhibit an abnormal development of the limb buds and the female genital tract. In particular, the histology of the uterus resembles that of the cervix and vagina, thus resulting in a phenotype that corresponds to a homeotic-like posterior transformation (Zhao and Potter, 2001). These data illustrate that some differences in the homeodomain, which is a highly conserved motif, lead nevertheless to the regulation of different genetic programs. As a matter of fact, even subtle differences in amino-acid sequences between Hox proteins can affect their gene targeting and/or transcription regulation properties, and/or, maybe more importantly, their cofactor binding.

To identify cofactors contributing to Hox specificity, various workers have examined Drosophila mutations that affect embryonic patterning. Using a genetic screen, the extradenticle (exd) gene product was first demonstrated to cooperate with Hox proteins during development (Rauskolb et al., 1995, Rieckhof et al., 1997). Homologs of this Drosophila gene were searched in various organisms and the corresponding proteins were merged

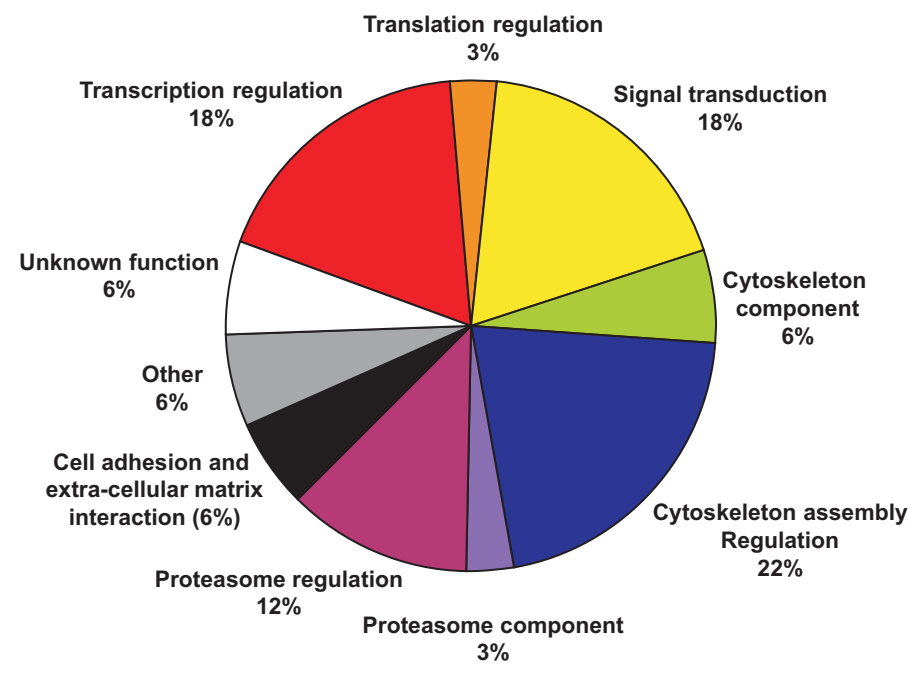

Fig.1. Identification of Pbx1 partners. Using the full-length $P b \times 1 b$ protein as bait in a yeast two-hybrid screen, positive clones were selected by their ability to activate reporter genes. True positive clones were then discriminated from false positives by GST-pull down analysis. Plasmid DNAs corresponding to putative Pbx 1 partners were purified, sequenced and identified by Blast analysis. The different putative partners were classified according to their biological functions. into the PBC subclass of the TALE family, which includes Pbx1 as the best mammalian-characterised member. By examining Drosophilamutants that phenocopy exdmutants, the homothorax ( $h$ th) gene was then discovered and demonstrated to participate in exd function (Rauskolb et al., 1995, Rieckhof et al., 1997). This gene and its vertebrate homologs, Meis and Prep, encode proteins that are classified in another subclass of TALE proteins referred to the Meis/Prep (=PKNOX1) subclass (Burglin, 1997). These latter proteins are implicated in the nuclear targeting (Abu-Shaar et al., 1999, Berthelsen et al., 1999, Rieckhof et al., 1997) and stability (Waskiewicz et al., 2001) of Pbx proteins.

While TALE cofactors undoubtedly increase Hox DNA binding specificity (Hox/Pbx DNA sites occur once every 8,200 base pair and $\mathrm{Hox} / \mathrm{Pbx} /$ Meis once every 420,000 base pairs), their ubiquitous expression raises two questions that have been only partly addressed during the past few years. Firstly, we need to know how these proteins take part in regional identity specification and whether they are themselves tightly regulated and/or associated with more specifically expressed factors. Secondly, it is necessary to elucidate their roles in embryonic regions that do not express Hox genes. In the following, we give some keys to understanding how these crucial developmental genes function as they modulate genetic programs during development.

\section{Pbx and Hox partnership}

Several biochemical and genetic approaches have shown that Pbx1 and Exd interact physically with Hox proteins, forming transcriptional complexes that modulate target gene regulation (for a review, see Moens and Selleri, 2006). The Hox/Pbx heterodimer binds cooperatively to bipartite target sites on DNA, increasing the binding affinity and specificity of each protein on gene promoters. More precisely, PBC proteins bind to Hox proteins from paralog groups 1 to 10 (Chang et al., 1995, Mann and Chan, 1996). This interaction is mediated by the binding of a small tryptophan-containing motif within the Hox protein to a hydrophobic pocket formed by PBC proteins. This motif known as "hexapeptide", "pentapeptide", or "YPWM", was more recently named PID for PBC Interaction Domain (In der Rieden et al., 2004). However, while the PID motif is clearly involved in $\mathrm{Hox} / \mathrm{Pbx}$ binding, it seems that the physical interaction is more complex than previously postulated. Indeed, recent structure-function analyses reveal that Exd is able to bind Hox proteins in the absence of the hexapeptide motif (Galant et al., 2002, Merabet et al., 2003). The complexity and diversity of the $\mathrm{Pbx} / \mathrm{Hox}$ interaction is based not only on the multiple partnerships between $\mathrm{Pbx}$ and the numerous members of the Hox family, but also on the existence of various isoforms of $\mathrm{Pbx}$ proteins. Indeed, most studies on Hox/ $\mathrm{Pbx}$ interactions were performed with $\mathrm{Pbx} 1$ or Exd proteins, while other PBC proteins were assumed to behave identically. However, even subtle differences in sequences between members of the $\mathrm{Pbx}$ family may lead to major in vivo modulations of $\mathrm{Hox} / \mathrm{Pbx}$ target gene expression. The biochemical characterization of the Pbx proteins, as well as analysis of the loss of function of the genes, can provide some keys for understanding the gene regulation triggered by these homeodomain proteins.

\section{Several Pbx proteins and isoforms}

The $P b \times 1, P b \times 2, P b \times 3$ and $P b \times 4$ genes encode products that 
share extensive sequence identity both within and flanking their DNA-binding homeodomains (up to $97 \%$ within their homeodomains) (Monica et al., 1991). Some of these genes give rise to several isoforms by alternative splicing. Indeed, Pbx proteins arise from differential splicing of $\mathrm{Pbx}$ transcripts to yield large (Pbx1a, Pbx2, Pbx3a and Pbx4) and short (Pbx1b, Pbx3b, $\mathrm{Pbx} 3 \mathrm{c}$ and $\mathrm{Pbx} 3 \mathrm{~d}$ ) forms of the respective proteins (Monica et al., 1991, Wagner et al., 2001, Milech et al., 2001). Based on biochemical studies, it is possible to discriminate clearly between different $\mathrm{Pbx}$ proteins and isoforms. Firstly, Pbx proteins do not exhibit exactly the same DNA binding properties. Although Pbx proteins recognize the same DNA consensus sequence in vitro, $\mathrm{Pbx} 1$ is not able to bind DNA alone, whereas $\mathrm{Pbx} 2$ and $\mathrm{Pbx} 3$ bind DNA without partners (Neuteboom and Murre, 1997). Secondly, while the ability of $\mathrm{Pbx}$ protein to homodimerize has been investigated using in vitro approaches, the resulting data remain controversial. While some authors demonstrated that only $\mathrm{Pbx} 3$ is able to homodimerize when bound to DNA (Neuteboom and Murre, 1997), others found that $\mathrm{Pbx} 1 \mathrm{a}$ and $\mathrm{Pbx} 1 \mathrm{~b}$ homodimerize as efficiently as $\mathrm{Pbx} 3$ (Calvo et al., 1999). Although this aspect of Pbx homodimerization has not been further explored, it could play a role in gene regulation through a competition between various partners. Indeed, several studies have addressed the importance of homodimerization for other homeodomain-containing transcription factors such as Oct1 (Poellinger and Roeder, 1989), Paired (Wilson et al., 1993), Cdx2 (Suh et al., 1994), Evenskipped (Hirsch and Aggarwal, 1995), Mix1 (Mead et al., 1996) and Pit1 (Jacobson et al., 1997). Homodimerization of Pbx proteins might be a way of preventing their interaction with other transcription factors and their binding onto certain gene promoters.

Although differential splicing is a feature of many homeobox transcripts, the functional consequences on the resulting products have been insufficiently explored. Ferreti and collaborators have demonstrated that the four $\mathrm{Pbx} 3$ isoforms translated from different transcripts of the $P b \times 3$ gene have distinct interaction specificities (Ferretti et al., 1999). The full-length isoform is designated as $\mathrm{Pbx} 3 \mathrm{a}$, while $\mathrm{Pbx} 3 \mathrm{~b}$ and $\mathrm{Pbx} 3 \mathrm{c}$ correspond, respectively, to a $\mathrm{C}$ and $\mathrm{N}$-terminus truncated isoform of the protein and $\mathrm{Pbx} 3 \mathrm{~d}$ consists of a protein truncated at both the $\mathrm{C}$ and $\mathrm{N}$ termini. As an example of their different biochemical properties, the two $\mathrm{Pbx} 3 \mathrm{c}$ and $\mathrm{Pbx} 3 \mathrm{~d}$ isoforms (lacking a large part of the two conserved PBC-A and PBC-B domains) are unable to bind to the Pbx-interacting factor Prep1 and interact only weakly with Meis, while other Pbx3 isoforms strongly interact. Consequently, the $\mathrm{Pbx} 3 \mathrm{c}$ and $\mathrm{Pbx} 3 \mathrm{~d}$ isoforms are unable to translocate with Prep1 into the nucleus and, as a result, another translocation system is necessary to import these proteins (Berthelsen et al., 1999). Studies on the interaction between $\mathrm{Pbx} 1$ and the pancreatic specific homeodomain factor Pdx1 (Peers et al., 1995) have provided convincing evidence of divergent properties between different $\mathrm{Pbx}$ isoforms. Indeed, $\mathrm{Pdx} 1 / \mathrm{Pbx} 1 \mathrm{~b}$ acts as a transcriptional activator through the activation domain carried by $\mathrm{Pdx} 1$, while $\mathrm{Pdx} 1 / \mathrm{Pbx} 1 \mathrm{a}$ acts as a transcriptional repressor complex. This divergence is due to the differential recruitment of corepressors. The Pbx1a isoform possesses a $\mathrm{C}$-terminus domain that binds the corepressor proteins SMRT and NcoR, while the Pbx1b isoform lacks this region and is unable to recruit these factors (Asahara et al., 1999).
In addition to their different biochemical properties, Pbx isoforms exhibit some specificity in their expression pattern. The Pbx1a isoform is restricted to the brain, whereas $\mathrm{Pbx} 1 \mathrm{~b}$ is expressed in the whole body. Furthermore, Pbx1b is the major embryonic isoform and Pbx1a is found mostly during adulthood (Schnabel et al., 2001). Although several Pbx transcripts can be detected in the same developing organ, the corresponding proteins often exhibit a specific cell distribution. In the embryonic pancreas, Pbx1a is not detected in acinar or $\beta$ cells, whereas $\mathrm{Pbx} 1 \mathrm{~b}$ is present exclusively in the nucleus of acinar cells. $\mathrm{Pbx} 2$ protein is detected in the nuclear and cytoplasmic fractions of the endocrine and acinar cells, while $\mathrm{Pbx3b}$ is present only in the cytoplasmic fractions of both cell lines (Swift et al., 1998). These studies highlight the fact that post-translational regulation mechanisms, in particular nuclear targeting, play a major role in $\mathrm{Pbx}$ function (this regulation is discussed below). Furthermore, expression of some $\mathrm{Pbx}$ isoforms seems to be favoured in certain pathologic contexts. Indeed, expression of $\mathrm{Pbx} 3 \mathrm{~d}$ is observed in normal cells, whereas Pbx3c expression is mostly found in leukaemia cells (Milech et al., 2001).

It is now possible to carry out functional studies of various isoforms encoded by one gene and interesting data are currently being reported. Recently, Noro et al. have shown distinct functions of homeodomain-containing and homeodomain-less isoforms encoded by homothorax (Noro et al., 2006). Using RNAi technologies in Drosophila, these authors showed that many of Hth's functions, including proximodistal axis patterning of the appendages and most Hox related activities, are executed by homeodomain-less isoforms, whereas antennal development is dependant on the $\mathrm{Hth}$ full-length isoform. They propose that alternative splicing of homeobox gene transcripts is a conserved evolutionary mechanism that expands the architectural diversity of $\mathrm{Hth} / \mathrm{Exd}$ and Meis/Pbx transcriptional complexes.

\section{Loss of function of $\mathrm{Pbx}$ genes}

Pbx1-deficient mice die at E15.5, displaying severe hypoplasia (lungs, liver, stomach, gut, kidneys and pancreas), ectopia (thymus and kidneys) or aplasia (spleen, adrenal gland) of multiple organs, as well as widespread defects of the axial and appendicular skeleton (Selleri et al., 2001). Skeletal malformations are observed in the proximal elements of limbs, in ribs and vertebrae and the skeletal structures of the second branchial arch undergo an anterior homeotic transformation into first arch-derived cartilages. Pbx3-deficient mice survive to term, but die within a few hours after birth from central respiratory failure due to abnormal activity of inspiratory neurons in the medulla where this gene is highly expressed (Rhee et al., 2004). Pbx1 and Pbx3 have extensively overlapping patterns of embryonic expression and these two related proteins could exhibit redundant functions. Indeed, mice lacking each of these genes display major phenotypes at sites where the mutated gene is singularly or mainly expressed. In addition, while mice with no $P b \times 1$ or $P b \times 3$ exhibit homeotic transformations highlighting the role of $\mathrm{Pbx}$ proteins as Hox cofactors, they do not perfectly phenocopy single or compound mutants for Hox or Hox-like genes. Thus, we can propose the hypotheses that either the PBC family members compensate each other in some tissues where their expression patterns are overlapping and/or that $\mathrm{Pbx}$ proteins have Hox-independent functions. Indeed, in contrast with precocious deaths caused by 
the loss of $\mathrm{Pbx} 1$ or $\mathrm{Pbx} 3, \mathrm{Pbx} 2$-deficient mice are viable and display no obvious phenotype, despite widespread expression of the gene during embryogenesis (Selleri et al., 2004); this suggests that loss of $\mathrm{Pbx} 2$ is compensated by another member of the PBC family.

As proposed for Hox proteins, the molecular mechanisms triggered by $\mathrm{Pbx}$ can be envisaged in terms of a "quantitative model". In this model, the various Pbx proteins may be largely redundant and a critical threshold of $\mathrm{Pbx}$ concentration would be required for normal development. This model is consistent with experiments performed in zebrafish, where the $\mathrm{Pbx}$ proteins are functionally equivalent (Waskiewicz et al., 2002). Nevertheless, to validate this model we need to analyse compound null mice to identify the interrelationships and overlapping functions of PBC proteins in different developmental pathways of organogenesis. Recently, Capellini and coworkers (Capellini et al., 2006) have shown that decreasing $P b \times 2$ dose in the absence of $P b \times 1$ affects limb development more severely than the loss of $P b \times 1$ alone (Selleri et al., 2001). Indeed, these authors demonstrated that compound $P b \times 1 / P b \times 2$ embryos, in addition to their proximal limb defects, exhibit novel and severe distal limb abnormalities, with $P b \times 1^{-1} / P b \times 2^{+1-}$ embryos displaying loss of distal hindlimb elements, whereas $P b \times 1^{-1-} / P b \times 2^{-1-}$ embryos lack hindlimbs altogether. These findings highlight the primary role of $P b \times 1$ and the crucial impact of spatiotemporal expression patterns of $P b \times 1 /$ Pbx2 on limb development. They are also consistent with a quantitative model in which the threshold of $\mathrm{Pbx}$ proteins would be crucial for limb development.

\section{Pbx proteins meet more partners}

\section{Homeodomain-containing proteins}

The well-characterized $\mathrm{Pbx}$ partners already mentioned are proteins belonging to the Meis/Prep (=PKNOX1) family. Mammalian Meis/Prep proteins are shown to dimerize with $\mathrm{Pbx}$ and independently with Hox from paralog group 9 to 13 (AbdB- like Hox proteins). The interaction between $\mathrm{Pbx}$ and Meis proteins requires each of their $\mathrm{N}$-termini. Trimeric complexes encompassing all three homeoproteins, Hox-Pbx-Meis/Prep, have also been characterized (for a review, see Moens and Selleri, 2006). While the majority of Hox monomers recognize a TAAT DNA core motif (Gehring et al., 1994), Hox-Pbx, Hox-Meis and Pbx-Meis heterodimers recognize larger motifs resulting in a higher affinity and specificity of DNA binding for these homeoproteins (Mann and Chan, 1996). Interestingly, recent data show that Hox/Meis interactions may extend to non-AbdB-like Hox proteins and that Meis proteins interact with different Hox groups using different interaction domains (Williams et al., 2005). The possible range of interactions demonstrated by these authors using a yeast twohybrid assay is expected to imply greater complexity in vivo, particularly in tissues that express multiple Meis isoforms. In addition, interaction between $\mathrm{Hox}, \mathrm{Pbx}$ and Meis is not restricted to interactions of the proteins bound on DNA. Indeed, gene expression regulation would depend on the three proteins, not necessarily in a DNA-bound trimeric complex, but also through protein-protein interactions where one or two members of these complexes could be non-DNA-binding partners. The mechanism by which the Hox/Pbx/Meis heterotrimer functions in gene regulation is currently under investigation. Huang and colleagues recently showed that, whereas Hoxb1 and $\mathrm{Pbx}$ are recruited rapidly to the Hoxb1 ARE (Autoregulatory Response Element), Meis is only recruited later, despite its constant availability (Huang et al., 2005). This finding suggests that Meis is not recruited as part of a preformed trimeric complex with Hox and Pbx. Furthermore, they mapped a C-terminus domain within the Meis 1 protein that mediates an increase in Hoxb1transcription level through its ARE in response to stimulation from TSA (trichostatin) or PKA (Protein Kinase A). In contrast, the Prep1 C-terminus is unresponsive to TSA and PKA stimulation, suggesting functional differences between Meis and Prep1 proteins. Finally, the multiple combinations occurring between the different forms of $\mathrm{Pbx}, \mathrm{Hox}$ or Meis-Prep families on DNA or in solution seem to play an important role not only in gene targeting but also in the strength of transcription regulation in response to specific cell signals.

As already mentioned, PBC proteins bind to Hox proteins from paralog groups 1 to 10 (Chang etal., 1995, Mann and Chan, 1996) through their PID motif. In fact, this motif has been described in other homeodomain proteins such as Engrailed (Peltenburg and Murre, 1996) and Pdx1 (Peers etal., 1995). Other PID motifs were searched for in proteins using an in silico approach and putative $\mathrm{Pbx}$ partners were found that belonged to the extended Hox, NK, LIM and the paired-box homeodomain-containing class of proteins (In der Rieden et al., 2004). Although a relatively important number of PID-containing proteins were identified by this approach, only some of these putative partners were shown to interact physically with Pbx1. Among functionally characterized $\mathrm{Pbx} 1$ partners, the pancreatic specific homeodomain factor Pdx1 regulates genes that are crucial for pancreas development and physiology such as those encoding insulin or somatostatin (Leonard et al., 1993). The somatostatin gene promoter is controlled by several cis-regulatory elements: a CRE element (recognized by the CREB factor and other related nuclear proteins), two TSEs (TSEI and TSEII for Tissue Specific Element I and II) and an element adjacent to the TSEI designated as UE-A (Goudet et al., 1999). The TSEI element is recognized by the Pdx1 and the UEA element is bound by a dimeric complex composed of a $\mathrm{Pbx}$ factor and the Prep1 protein. It has been demonstrated that Pbx1 and Prep1 proteins are able to bind cooperatively to the UE-A site, whereas neither protein can bind this site alone. Furthermore, Pbx1 and Prep1 have no effect on the intact somatostatin promoter, but they produce a drastic activation when the pancreatic homeodomain factor Pdx1 is also co-expressed. Thus, the full activation of the somatostatin promoter is mediated by a cooperative interaction between the Pbx1-Prep1 heterodimeric complex and the pancreatic factor Pdx1 bound to the nearby TSEI site. These observations suggest that the Pbx1-Prep1 heterodimer possesses an activation capacity that is highly dependent on spatial organization. It has also been postulated that, in the context of the somatostatin promoter, one function of $\mathrm{Pdx} 1$ is to promote functional interactions between the basal machinery and the Pbx1-Prep1 heterodimer. In addition, Peers and coworkers showed that Pdx1 promotes somatostatin expression in $\delta$-cells by binding cooperatively with $\mathrm{Pbx} 1$ to the TSEII site while it induces insulin expression in $\beta$-cells, by acting cooperatively with the helix-loop-helix E47 protein (Peers et al., 1995). These observations suggest that the commitment of cells within the islet lineage to express either insulin or somatostatin may depend on the relative expression of $\mathrm{E}-\mathrm{box}$ binding protein $\mathrm{E} 47$ versus $\mathrm{Pbx} 1$ 
proteins.

The regulation of another target gene of $\mathrm{Pdx} 1$, the pancreatic elastase 1 gene ( $E L A$ ), also involves specific members of the $\mathrm{PBC}$ and MEIS families. This regulation is mediated through a 10bp element (designated as element B) within a transcriptional enhancer of the ELA1 gene promoter (Swift et al., 1998). Using transient transfection assays, it has been demonstrated that this B element is responsible for cell-specific expression of the $E L A 1$ gene. Indeed, in exocrine acinar cells, the B element cooperates with flanking sequences of the ELA1 enhancer and the activation of the gene is promoted by a complex comprising $\mathrm{Pdx} 1, \mathrm{Pbx} 1 \mathrm{~b}$ and Meis2. Conversely, in endocrine $\beta$-cells, the $B$ element triggers gene expression in the absence of other activated enhancer elements. Thus, while activation of the $\mathrm{B}$ element can be mediated by $\mathrm{Pdx} 1$ without $\mathrm{Pbx} 1 \mathrm{~b}$ and Meis 2 in acinar cells, it fails to be functional in $\beta$-cell lines. This study suggests that Pbx and Meis are regulated in a cell-specific manner within an organ and their association with $\mathrm{Pdx} 1$ controls the nature of the transcriptional activity of the transcription factor in exocrine versus endocrine cells. A subsequent study showed that the activity of the pancreas-specific ELA1 enhancer in acinar cells requires the cooperation of the trimer-binding B element with a nearby element binding to the pancreatic transcription factor PTF1 (Liu et al., 2001). This latter factor comprises a bHLH heteromultimer that minimally contains the acinar cell-specific p48 protein and an ubiquitous E-box binding protein (REB in rats, HEB in humans, ALF1 in mice). When all partners are present in the nucleus of acinar cells, $\mathrm{Pdx} 1$ first recruits $\mathrm{Pbx} 1 \mathrm{~b}$ and they together bind in tandem to adjacent Pdx1 and Pbx half-sites. Pbx1b then recruits Meis $2 b$ to the DNA-bound complex, whose presence is required for both the transcriptional activity of the Pdx1/Pbx1b/Meis2 trimer and its cooperation with PTF1. Although the $\mathrm{N}$-terminal activation domain of $\mathrm{Pdx} 1$ is essential to increase the transcriptional activity of the trimer, the mechanism by which it operates remains unclear. In addition, the mechanism of the cooperation between $\mathrm{Pdx} 1$ and p48 within the complex is not known, but it is likely that the two proteins interact either to stabilize each other's binding to DNA or to recruit coactivators to facilitate transcriptional activation.

\section{Non-homeodomain containing proteins}

HPIP (Haematopoietic Pbx1 Interacting Protein) is a nonhomeodomain protein that was identified as a partner of PBC proteins in haematopoietic tissues (Abramovich et al., 2000). This protein does not possess any known DNA binding domain, but modulates the function of PBC transcription factors through protein-protein interactions. More precisely, this protein was demonstrated to prevent the DNA binding of Hox/Pbx complexes in vitro and inhibit the transcriptional activation triggered by $\mathrm{E} 2 \mathrm{a}$ PBX1 oncoprotein in transient transfection assays. The biological relevance of HPIP's ability to modulate $\mathrm{Pbx}$ function remains to be assessed in a more physiological context. A recent report (Manavathi etal., 2006) shows that HPIP is able to physically bind estrogen receptor $\alpha(E R \alpha)$ and that a HPIP-microtubule complex could regulate estradiol-ER responses in mammalian cells. Unfortunately, the involvement of Pbx proteins in such pathway has not been investigated yet by the authors.

Recently, we identified a new Pbx1 partner called ZFPIP for Zinc Finger Pbx1 Interacting Protein that is able to inhibit the in vitro DNA binding of $\mathrm{Hox} / \mathrm{Pbx}$. This protein, exhibiting numerous $\mathrm{C} 2 \mathrm{H} 2$ zinc-finger motifs, a NLS and highly conserved domains, is likely to take part with $\mathrm{Pbx} 1$ to important gene regulation processes (Laurent et al., 2007). The pattern of expression of ZFPIP overlaps with that of Pbx1 in embryo, suggesting that it could function along with $\mathrm{Pbx} 1$ throughout development. A growing body of evidence suggests that a global network of conserved $\mathrm{C} 2 \mathrm{H} 2$ zinc finger transcription factors may contribute to the patterning of the embryo in partnership with Hox proteins (Mahaffey, 2005). Thus, ZFPIP is likely to impact on Hox/Pbx function in vivo, so we are currently investigating the genetic and physiological interaction between ZFPIP and Hox/Pbx proteins.

\section{Pbx proteins and cell signaling}

While the role of $\mathrm{Pbx}$ in cell signaling is Hox gene dependent most of the time, some Hoxindependent mechanisms have also been reported. The following paragraphs provide an overview of $\mathrm{Pbx}$ involvement in cell signaling.

\section{Pbx proteins interact with partners involved in cell signaling}

\section{$P b x$ and TGF $\beta$ signaling}

Members of the TGF $\beta$ family (activin and BMP) are secreted proteins that regulate a broad range of cellular responses during development. They act through two types of serine/threonine transmembrane receptor kinases (RTK), which mediate the phosphorylation of intracellular receptor-specific Smad proteins (Smad2-3 and Smad1 are phosphorylated upon TGF $\beta$ s and BMP signaling, respectively). These phosphorylated Smad proteins then associate with a common partner, Smad4 and translocate into the nucleus (Attisano and Wrana, 2002). Several data have highlighted the link between TGF $\beta$ signaling and Hox proteins. As an example, the osteoprotegerin gene is regulated by a complex of Smads/HoxC-8 proteins in response to BMP (Wan et al., 2001). Recently, a comprehensive study performed on several different paralog Hox proteins showed that they act as general downstream DNA- binding proteins in the BMP signaling pathway and that their transcriptional activities are regulated by Smads (Li et al., 2006). Whereas fewer examples can be cited of interaction between this TGF $\beta$ signaling and Pbx proteins, they are nevertheless informative about $\mathrm{Pbx}$ function. In particular, Bailey and collaborators (Bailey et al., 2004) identified Pbx1 and Prep1 as Smad partners within a trimeric complex involved in the regulation of the $\mathrm{FSH} \beta$ gene by activin. The $\mathrm{FSH} \beta$ gene promoter was demonstrated to be bound by Prep1/Pbx1/Smad4 (Bailey et al., 2004) and that Pbx1/Prep1 were able to interact physically with Smad2, Smad3 and Smad4; this cooperative association of Pbx1/ Prep1 with Smad proteins is likely to increase the DNA binding affinity of each protein and modulate their selection of target sites. Thus, it is proposed that $\mathrm{Pbx} 1$ and Prep1 proteins bound to the $\mathrm{FSH} \beta$ promoter recruit Smad proteins and/or stabilize their binding to the promoter after Smad nuclear translocation in response to activin signaling. These studies suggest an important link between $\mathrm{Pbx}$ and Smad proteins in target gene regulation and identify Pbx1 as novel mediators of activin action.

\section{Pbx and nuclear receptors}

Nuclear receptors (NR) are transcription factors that regulate 
the activity of complex gene networks (Mangelsdorf et al., 1995). This superfamily is typically subdivided into three families: the steroid receptor (SR), thyroid/retinoid (TR/RXR) and orphan receptor families. The transcription of the malic enzyme gene in chick embryo hepatocytes is stimulated by thyroid hormone (T3) through a cluster of five T3 response elements. This activation is greatly enhanced through an accessory element flanking the cluster of T3 response elements and designated as region $\mathrm{E}$. The region $\mathrm{E}$ contains four consecutive $\mathrm{Pbx} /$ Meis 1 half-sites that can be bound by $\mathrm{Pbx} /$ Meis 1 complexes in several configurations, one of which is able to mediate a full activation of malic enzyme gene (Wang et al., 2001). These authors demonstrated that the transcription enhancement of the malic enzyme gene is mediated by a physical interaction between Pbx1 and the nuclear T3 receptor- $\alpha$. In addition, this interaction is enhanced by the presence of T3. Although these authors did not address the mechanism of this transcription enhancement, they hypothesized that the complex formation between TR/RXR and Pbx/Meis 1 may facilitate the recruitment of coactivators onto the malic enzyme promoter. Their study and others suggest that complexes containing $\mathrm{Pbx} /$ Meis-Prep1 function as accessory proteins that potentiate other more specific transcription factors (Berthelsen et al., 1998, Liu et al., 2001, Peers et al., 1995).

The prolactin gene (PRL3) transcription can be activated either by Pit-1/GHF-1 that are specifically expressed in pituitary cells or, to a lesser extent, by Oct1 (a POU-homeodomain containing protein) and $\mathrm{Pbx} 1$ in non-pituitary cells (Subramaniam et al., 1998). The PRL3 promoter contains a negative glucocorticoid response element ( $\mathrm{nGRE}$ ) that prevents the expression of the gene in non-pituitary cells when it is bound by the nuclear glucocorticoïd receptor (GR). These authors demonstrated that the gene can nevertheless be expressed in these cells under some physiological conditions. Indeed, non-pituitary cells confer increased expression of the gene through the binding of the ubiquitously expressed Oct-1 to an AT-rich sequence present in the PRL promoter. They further showed that full transcriptional activity of the gene required the binding of $\mathrm{Pbx} 1$. Interestingly, both Oct-1 and Pbx1 binding to the PRL3 nGRE were found to be required for glucocorticoid repression. They proposed that the mechanism of GR-mediated transcriptional repression involves either the displacement of these activating factors or some interference with their activation potential. The involvement of the homeobox protein $\mathrm{Pbx} 1$ in glucocorticoid repression via an $\mathrm{nGRE}$ highlights a new role for this protein in interfering with nuclear receptors signaling.

In contrast with the repressive effect of GR on the Pbx1-bound PRL3 nGRE, glucocorticoids were shown to synergize with retinoic acid $(R A)$ in enhancing the transcriptional activation of a reporter
Cell signaling

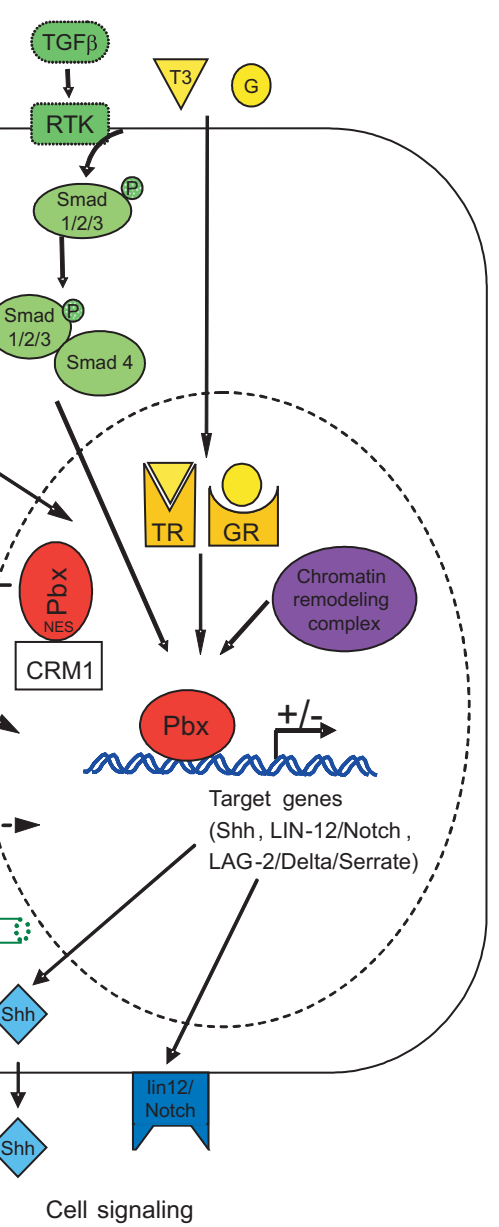

Fig. 2. Pbx is at the crossroads of several signaling pathways. Pbx is able to integrate TGF $\beta$ and nuclear hormone stimuli, as well as initiate transcription of genes involved in sonic with specific transcription factors and chromatin-remodeling enzymes and contributes to the assembly of transcriptional regulation machinery onto target genes.

gene carrying the Hoxb1-ARE. This enhancement was shown to be mediated by the binding of the $\mathrm{Pbx} 1 / \mathrm{Hoxb} 1$ heterodimer (Subramaniam et al., 2003) and it was proposed that the GC/RA synergy is built on a physical interaction between the GR and Pbx1 proteins. However, according to these authors, it is not clear whether GR acts as a direct coactivator or as a factor allowing the recruitment of other transcriptional activators onto the promoter. Since GR and Pbx1 are ubiquitously expressed, numerous Pbx1regulated genes may be important targets for GC-mediated "cross-talk". Supporting this hypothesis, the interaction of GR with homeodomain proteins has been shown to interfere with developmental processes in Xenopus laevis and in zebrafish (Gao et al., 1994, Wang et al., 1999).

\section{Pbx proteins induce expression of factors involved in cell signaling}

If $\mathrm{Pbx}$ proteins can be mediators of certain signaling pathways, they can also initiate the expression of key proteins involved in cell transduction signals. In cooperation with $\mathrm{Hox}$, $\mathrm{Pbx}$ proteins in- 
duce the transcription of sonic hedgehog during limb-bud development (Capellini et al., 2006). The involvement of Hox protein Lin 39 and its Exd/Pbx-like cofactor Ceh-20 in Notch-mediated signaling during Caenorhabditis elegans vulval development has been recently investigated (Takacs-Vellai et al., 2007). The authors demonstrated that both Lin-39 and Ceh-20 are required for the expression of the Lin-12/Notch receptor and one of its ligands in the vulval precursor cells, rendering them competent for the subsequent Lin-12/Notch induction events. These results suggest that the transcription factors Lin-39 and Ceh-20, which function at the bottom of the RTK/Ras and Wnt pathways in vulval induction, serve as major integration sites in coordinating and transmitting signals to the Lin-12/Notch cascade to regulate vulval cell fates. Figure 2 presents a schematic diagram of the central role of PBC proteins in inducing and mediating cell signaling pathways during development.

\section{Pbx proteins interact with chromatin-remodeling pro- tein complexes}

The differentiation of muscle cells is orchestrated by four myogenic regulatory genes corresponding to MyoD, Myogenin, Myf5 and Mrf4. These bHLH (basic Helix Loop Helix) factors associated with $\mathrm{E} 2 \mathrm{a}$, bind and activate multiple $\mathrm{E}$ box elements containing muscle specific promoters (Arnold and Winter, 1998). In transfection assays, the binding of Pbx1-Meis1 to an element adjacent to the $E$ box enhances transcriptional activation by $E 2 a-$ MyoD, suggesting a synergistic effect between MyoD/E2a and $\mathrm{Pbx} /$ Meis heterodimers. Since myogenic bHLH proteins exhibit a PID motif, it has been suggested that this synergy might be mediated by the physical interaction between Pbx1 and bHLH proteins (Knoepfler et al., 1999). Indeed, some authors conclude that the $\mathrm{Pbx} 1 /$ Meis complex is constitutively bound to the myogenin promoter, whereas association of MyoD with the myogenin promoter increases during differentiation (Bergstrom et al., 2002). To better understand the mechanism of the Myogenin transcriptional activation, a temporal analysis of protein binding events on its promoter was performed by ChIP experiments (Berkes et al., 2004). These authors showed that MyoD interacts with the promoter indirectly via $\mathrm{Pbx} 1$ and recruits the SWI/SNF enzymes of the chromatin-remodeling complex, which then facilitates the binding of MyoD and other regulators and finally leads to transcriptional activation of the Myogenin gene. Actually, the SWI/ SNF enzymes physically interact with histone acetyltransferases (HATs), histone deacetylases (HDACs) and methyltransferases and thus have the potential to coordinate chromatin-remodeling activities; this complex was moreover shown to activate or repress expression of a subset of genes (Martens and Winston, 2003, Sif, 2004). The recruitment of the SWI/SNF chromatinremodeling enzymes on the myogenin promoter is mediated by physical interactions between Brg1 (an ATPase belonging to the SWI/SNF complex) and Pbx1, as well as between Brg1 and MyoD (de la Serna et al., 2005). These results are consistent with other data suggesting that SWI/SNF chromatin-remodeling enzymes are generally recruited during the later stages of an activation process, after the assembling of factors onto promoters (Martens and Winston, 2003, Salma et al., 2004, Soutoglou and Talianidis, 2002, Spilianakis et al., 2003). While the study of Berkes et al. (2004) demonstrated a direct interaction between Pbx1 and the chromatin remodeling machinery, other data indicated that $\mathrm{Pbx} 1$ proteins are linked to HDACs and HATs and thus have the ability to repress or activate transcription upon specific cell signaling. As already mentioned above, the Pbx1/Pdx1 heterodimer can alternately inhibit or activate the transcription of pancreas-specific genes. The $\mathrm{Pbx} 1 \mathrm{~b} / \mathrm{Pdx} 1$ complex triggers the transcriptional activation through the recruitment of CBP, a histone acetylase, whereas $\mathrm{Pbx} 1 \mathrm{a} / \mathrm{Pdx} 1$ represses transcription by binding of $\mathrm{NcoR}$ and SMRT (Asahara et al., 1999). Although the mechanism by which NCoR and SMRT repress target gene expression is not completely clear in this case, they were previously shown to associate with histone deacetylases via Sin3 complexes (Alland et al., 1997, Heinzel et al., 1997, Nagy et al., 1997). Thus, NCoR and SMRT may block Pdx1 activity by opposing CBP-mediated nucleosome acetylation. The Hoxb1autoregulatory element comprises three Hox-Pbx binding sites. Although this enhancer fails to activate reporter-gene expression in P19 cell monolayers treated by retinoic acid (RA), it becomes functional when the cells are cultured in aggregation in the presence of RA. Indeed, the Hoxb1/Pbx1 heterodimer is able to switch from a repressor to a net activator after cell aggregation or PKA signaling (Saleh et al., 2000). The precise mechanism of this conversion is unclear, but it was shown that the repressive activity was mediated by a physical interaction between $\mathrm{Pbx} 1 \mathrm{a} \mathrm{N}$-terminus and a corepressor complex including HDAC1, HDAC3, mSIN3B and N CoR/ SMRT, while the activation was mediated by the PKA-facilitated recruitment of CBP by Hoxb1. It is interesting that Pbx1/Hoxb1 dimer can be switched from repressor to activator in response to PKA signaling or cell aggregation, since this suggests that cell signaling mediated by intracellular CAMP could be determinant for Hox/Pbx function. A number of studies demonstrate that CBP interacts with various $\mathrm{Pbx} /$ partner complexes and could modulate gene transcription by this interaction (Asahara et al., 1999, Saleh et al., 2000, Shen et al., 2001). Shen and colleagues (Shen et al., 2001) have shown that CBP is also able to prevent Hox DNA binding in vitro and that the interaction between Hox and CBP inhibits CBP histone acetylase activity. Hence, these mutual inhibitory interactions might explain the inability of CBP to potentiate the low level of gene activation induced by Hox proteins in a range of reporter assays. While these in vitro data should be explored in a more physiological context, we can nevertheless speculate about the significance of this $\mathrm{CBP} / \mathrm{Hox}$ interaction in vivo. By inhibiting Hox DNA binding, the interaction of CBP with Hox proteins could be a switch in some developmental genetic programs. Indeed, the interaction between CBP and Hox proteins would result in the release of Hox proteins from target genes, as well as the inhibition of CBP activity. In such a model, we can question the role of non-homeodomain forms of Hox proteins. Along with other authors, we have indicated that some Hoxgenes produce non-homeodomain isoforms (Dintilhac et al., 2004, Komuves et al., 2000). Some of these truncated Hox proteins have the ability to interact with CBP as efficiently as the full-length isoforms. In particular, we showed that HoxA9T, a homeodomainless isoform of HoxA9, is able to bind CBP and could consequently be a competitor of typical Hox proteins for CBP (Dintilhac et al., 2004). Such truncated forms of homeodomain proteins probably play an important role in sequestering specific cofactors and, consequently, in the gene regulation of specific Hox target genes. 
Another example of link between $\mathrm{Pbx} 1$ and chromatin-remodeling protein complexes is provided by the transcription factor FoxC1, a member of the Forkhead Box (FOX) gene family. FoxC1 has been implicated in the specific formation of multiple structures such as eyes, axial skeleton, somites, heart and surrounding vasculature, as well as the urogenital system (Kidson et al., 1999, Kume etal., 2000, Kume et al., 2001, Winnier etal., 1999). FoxC1 was recently reported by Berry and colleagues (2005) to interact with Pbx1a in the nucleus, especially in $\mathrm{HP} 1 \alpha$-rich (heterochromatin Protein 1) nuclear compartments. Once localized in these regions, FoxC1 is unable to recruit the necessary coactivators required to initiate transcription. However, it is still unclear whether the localization of FoxC1 in the HP1 $1 \alpha$-rich regions is the cause or consequence of FoxC1-Pbx1a-mediated inhibition. The authors suggest that $\mathrm{Pbx} 1 \mathrm{a}$ is a component of the transcriptional inhibitory network acting on FoxC1 in cells (Berry et al., 2005).

\section{$\mathrm{Pbx}$ acts as a bridging protein within the transcriptional complex}

As mentioned above, $\mathrm{Pbx}$ proteins interact with a wide range of proteins on target genes. These Pbx interacting partners, corresponding to homeodomain (Hox, Meis/Prep, Pdx1) and nonhomeodomain (FoxC1, HPIP, ZFPIP, Smad, NR, MyoD) proteins, display more temporally and/or spatially restricted expression during development than Pbx. As such, they should be considered as Pbx cofactors and they are designated in figure 3 by XPIP (X Pbx Interacting Proteins, with $\mathrm{X}$ corresponding to any specifically expressed transcription factor Interacting with $\mathrm{Pbx}$ ). This concept is consistent with the comparison of the phenotypes of XPIPs and Pbx-null mice. The abnormalities observed in mice lacking $\mathrm{Pbx} 1$ are much more widespread than those observed in XPIP-null mice. In addition, Pbx proteins interacting with Meis/ Prep proteins form heterodimers which, in numerous transient transfection assays, display no drastic transcriptional activity. Indeed, as mentioned by several authors, the heterotrimers made up of $\mathrm{Pbx} /$ Meis/XPIP are more efficient transcriptional regulators than $\mathrm{Pbx} /$ Meis heterodimers, suggesting that the latter need to cooperate with other transcription factors. This cooperation can occur only on extended promoter sequences that are generally not used in reporter assays. The articles cited in this issue report several examples of such cooperation mediated by physical interactions with $\mathrm{Pbx}$ and other specific transcription factors. Thus, it seems that $\mathrm{Pbx}$ target gene transcription can be modulated by a dynamic organization of these factors in response to different cell signals. Within the complex, each of the partners is able to recruit chromatin-remodeling enzymes such as CBP, HAT, HDAC and the SWI/SNF proteins. The transcriptional effect of these complexes is likely to correspond to the sum of these opposite and/or synergetic enzyme activities and results from the integration of several signaling pathways such as those involving Smad, PKA and nuclear receptors.

A detailed analysis of $\mathrm{Pbx} 1$-null mice phenotypes showed that $\mathrm{Pbx}$ function is crucial during development and especially for organogenesis events. Indeed, although $\mathrm{Pbx}$ is not necessary for the initiation step of organogenesis, $\mathrm{Pbx}$ is required in several other steps of organ development (Selleri et al., 2001, Brendolan et al., 2005, DiMartino et al., 2001, Schnabel et al., 2003, Manley etal., 2004, Dutta etal., 2001). In mice where the Pdx 1 gene lacks the PID-encoding portion, Dutta and colleagues have shown the promotion of a complete pancreatic genetic program. They suggest that $\mathrm{Pdx} 1$ monomers and $\mathrm{Pdx} 1 / \mathrm{Pbx} 1$ heterodimers trigger genetic programs that may differ (Dutta et al., 2001). These results support the hypothesis that homeoproteins can regulate target enhancers without cofactors and through monomer binding sites (Galant et al., 2002).

In the latter cited studies, the search for genetic interactions of $\mathrm{Pbx}$ with developmental markers failed to show the involvement of $\mathrm{Pbx}$ in a well defined genetic pathway. According to the overall data, we propose a model where XPIP/Pbx heterodimers function as adaptators onto promoters to integrate information from several signaling pathways after the initiation of organogenesis genetic programs (Fig. 3). We propose that, during organogenesis initiation, $\mathrm{Pbx}$ target gene promoters are positionally marked by XPIP, which then cooperate with $\mathrm{Pbx}$ and other regulator factors to activate or repress transcription. From most examples found in the literature, we can propose that XPIP is able to bind to some consensus sites as a monomer (Galant et al., 2002). After $\mathrm{Pbx}$ becomes available in the nucleus by nuclear import, XPIP may be partly displaced by $\mathrm{Pbx}$ and the newly formed heterodimers will bind to adjacent dimeric sites. This shift of XPIP from monomeric to dimeric binding sites should occur since the interaction between XPIP and monomeric sites is weaker than between XPIP/Pbx and dimeric binding sites. In this way, Meis/ Prep could be recruited either as a non-DNA binding partner or as a DNA-binding partner (in this latter, the complex binds to a trimeric binding site) to stabilize the assembly. Thus, the formation of XPIP/Pbx heterodimers (or heterotrimers if Meis/Prep is involved) is responsible for the recruitment of chromatin-remodeling enzymes that likely allows the stable DNA binding of other transcription factors. This recruitment is possible due to $\mathrm{Pbx}$ bridging properties and explains the cooperation between adjacent regulatory sites bound by various transcription factors assembled around $\mathrm{Pbx}$. The transcription regulation of target genes would correspond to the integration of antagonistic or synergistic signaling pathways by $\mathrm{Pbx}$. Hence, organogenesis genetic programs would correspond to the modulation of silencing, maintenance or enhancing of key gene expression by $\mathrm{Pbx}$ proteins and their various partners.

\section{Sub-cellular localization of $\mathrm{Pbx}$ proteins is tightly regu- lated}

The above sections highlight the role of $\mathrm{Pbx}$ proteins in gene regulation within transcriptional complexes. The presence of Exd/ Pbx protein in the nucleus of cells is thus determinant for the adjustment of appropriate genetic programs. During Drosophila development, Exd is cytoplasmic in distal area appendages, while it is nuclear in proximal areas. The misexpression of Exd in the nuclei of distal cells blocks distal development giving rise to truncated appendages (Gonzalez-Crespo et al., 1998, GonzalezCrespo and Morata, 1996). Pbx1 nuclear location is also crucial for the correct development of proximal limb structures in vertebrates. Indeed, Pbx1-deficient mice display malformations involving only proximal skeletal elements in regions where $\mathrm{Pbx} 1$ is nuclear. By contrast, the distal elements are unaffected in these mice (Selleri et al., 2001). Numerous other studies show that the nuclear/cytoplasmic distribution of Pbx1 is subject to complex 

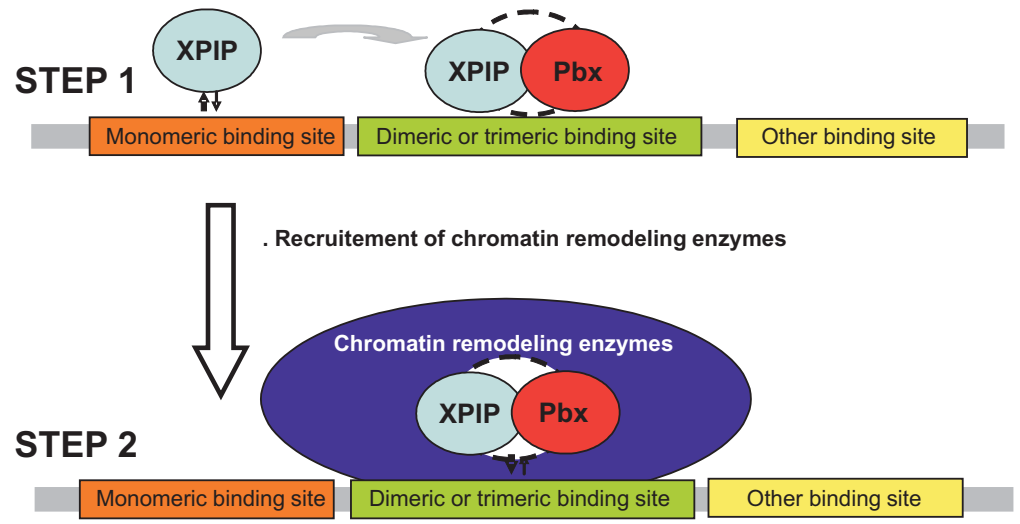

. Integration of antagonistic or synergistic signaling pathways . Binding of other transcription factors

. Organization of a transcription regulation complex by bridges via $\mathrm{Pbx}$
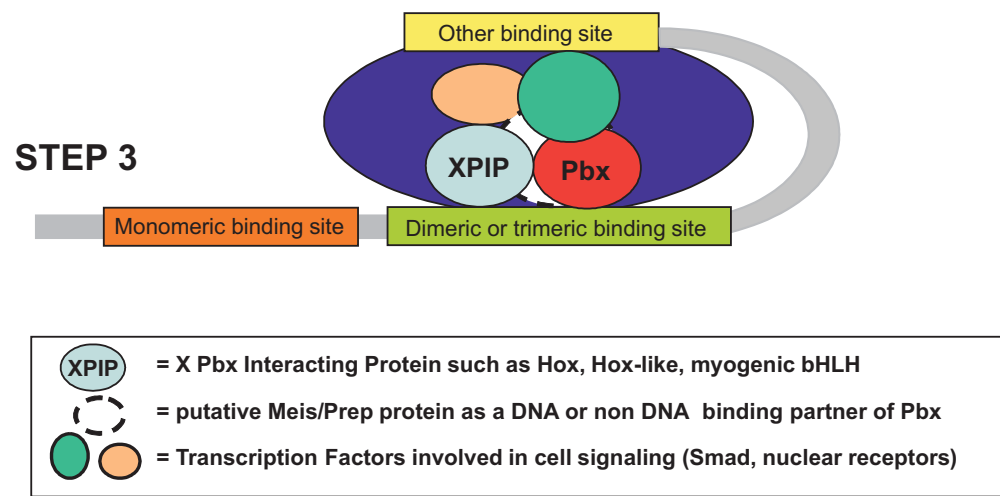

Fig. 3. Pbx proteins have a major role in integrating cell signaling and triggering subsequent developmental genetic programs. During development, differentiation genes are firstly bound by monomeric XPIP ("X" $P b x$ Interacting Protein) and Pbx/Meis (or Pbx/Prep) dimer. Then, XPIP is recruited by the Pbx/Meis dimer (Meis could be involved in the complex either as a non-DNA or DNA-binding partner). The XPIP/Pbx/Meis heterotrimer is subsequently able to recruit chromatin-remodeling enzymes that allow stable DNA binding of other transcription factors. The target gene is thus transcribed at a rate defined by the overall complex interaction with the basal transcriptional machinery. (Step 1) Developmental genetic program initiated by XPIP/Pbx proteins; (Step 2) Integration of cell signaling pathways; (Step 3) Modulation of developmental genetic programs by Pbx-containing transcription complex.

regulatory mechanisms that result from an interplay between several Pbx interacting partners binding to the NLS (Nuclear Localization Signal) and NES (Nuclear Export Signal) of Pbx1. Indeed, the region spanning amino acids 45-90 of PBC-A contains two independent NESs able to mediate $\mathrm{Pbx} 1$ nuclear export through the CRM1 (exportin 1) nuclear export receptor (KilstrupNielsen et al., 2003). Pbx1 also contains two cooperative NLSs within the homeodomain that are inhibited when masked by an intramolecular interaction between the $\mathrm{N}$-terminus and the homeodomain of $\mathrm{Pbx1}$ (Saleh et al., 2000). Furthermore, the competition in nuclear import and export signals can be influenced in a cell-specific manner. For example, in cells expressing
Meis/Prep proteins, the binding of Pbx1 to Meis/Prep proteins leads to a conformational change exposing the $\mathrm{Pbx} 1 \mathrm{NLS}$, which is then nuclear targeted (Berthelsen et al., 1999, Saleh et al., 2000). The sub-cellular location of $\mathrm{Pbx} 1$ is also regulated by a post-translational mechanism. Indeed, the activation of protein kinase A leads to phosphorylation of $\mathrm{Pbx} 1$ and this enhances its nuclear localization (Kilstrup-Nielsen et al., 2003). Recently, it has been proposed that the actin-binding protein Filamin A (FLNA) can mediate the nuclear localization of Pbx1a either by influencing its phosphorylation status or by participating in Pbx1-Meis/Prep assembly. However, it is not yet known whether FLNA directly binds to Pbx1 or Meis/Prep proteins and how it regulates the correct nuclear localization of Pbx1 (Berry et al., 2005). It has also been demonstrated that the NMHCB (non-muscle myosin heavy-chain B) has a Pbx1 cytoplasmic retention function. Furthermore, the $\mathrm{Pbx} 1$ region involved in NMHCB interaction overlaps the region needed for Meis1a binding, suggesting that the subcellular location of $\mathrm{Pbx} 1$ may result from a competition between several pathways (Huang et al., 2003). The $\mathrm{Pbx1/NMHCB}$ interaction also supports the hypothesis that the actin cytoskeleton may play a role in the accurate regulation of the nuclear import of $\mathrm{Pbx} 1$. In agreement with this idea, the Haematopoietic Pbx1 Interacting Protein (HPIP), first identified as a PBX partner (Abramovich etal., 2000), has the potential to be a nucleocytoplasmic shuttle protein since it contains a NLS, a NES and a cytoskeletonbinding domain (Abramovich et al., 2002). Thus, the association of HPIP with the cytoskeleton may provide a regulatory mechanism controlling the availability of functional nuclear $\mathrm{Pbx}$ proteins. In addition, other components of the cytoskeleton such as tubulin $\alpha$ and $\beta$ were identified in our two hybrid screen for $\mathrm{Pbx} 1 \mathrm{~b}$ interacting proteins (Fig. 1). These interactions are expected to promote Pbx1 cytoplasmic retention.

Although numerous studies have been performed to investigate the regulation of $\mathrm{Pbx}$ sub-cellular localization, some questions remain unresolved. In particular, we might ask how different $\mathrm{Pbx}$ proteins and/or isoforms present in the same cell type display divergent sub-cellular distributions. This is illustrated by the localization of Pbx1a in the nucleus of pancreatic acinar cells, while Pbx2 is nucleocytoplasmic and $\mathrm{Pbx} 3 \mathrm{~b}$ exclusively cytoplasmic in the same cells. The regulation of $\mathrm{Pbx}$ localization is thus definitely more complex than initially envisaged with the identification of Meis/Prep protein as a unique Pbx nuclear/ cytoplasmic shuttle (Fig. 2). Moreover, the presence of different isoforms existing in the Meis/Prep family precludes multiple partnerships and multiple ways of regulating $\mathrm{Pbx}$ localization.

\section{Conclusion}

This review highlights the fundamental role of $\mathrm{Pbx}$ proteins in initiating, mediating and integrating physiological and cellular contexts during development (Fig. 2). In their position downstream of crucial signaling pathways, Pbx proteins are able to initiate developmental programs and, by interacting with cellsignaling effectors, they can also adapt new genetic networks. 
This functional plasticity might explain the localisation of the proteins in critical areas of developing organs. Indeed, the detailed description of Pbx1 expression in mice clearly demonstrates the presence of this protein not only in proliferating zones, but also in non-cycling cells of the developing embryo (Schnabel et al., 2001). As suggested by these authors, Pbx1 expression during organogenesis indicates a potential function in determining cell fate in a variety of tissues that depend on mesenchymalepithelial interactions for their coordinated morphogenesis. We can thus imagine that $\mathrm{Pbx}$ proteins are able to switch from one gene regulatory network to another, allowing proliferating cells to go through a genetic differentiation program necessary to obtain specialized cell types in functional organs. The overall results of studies in the literature indicate that $\mathrm{Pbx}$ proteins functionally interact with a wide variety of transcription factors, thus forming heterodimers, heterotrimers or multimers on promoter target genes that play key roles in cell fate. These Pbx-associated factors often possess a PID that is an imperfectly conserved motif, indicating that competition between these PID-bearing proteins could occur under certain conditions. The positive or negative effects of $\mathrm{Pbx}$-containing complexes on target-gene transcription depend on their composition, with each component participating directly or indirectly in the recruitment of chromatin-remodeling enzymes such as HAT, HDAC, CBP or the whole SWI/SNF complex. The level of transcriptional regulation mediated by $\mathrm{Pbx} /$ partners seems to be a balance between the opposite activities of chromatin-remodeling enzymes that they recruit. This overall assembly of transcriptional complexes onto gene promoters would result in the expression of specific gene networks, integrated by cells to ultimately undergo mitosis or specific differentiation programs.

\section{Acknowledgments \\ We are indebted to Dr. V. Dupé and Dr. H. B. Osborne for helpful comments on the manuscript. AL was supported by a grant from the "Conseil Régional de Bretagne". This work was supported by the CNRS and by grants from "Rennes Métropole" and the "Conseil Régional de Bretagne".}

\section{References}

ABRAMOVICH, C., SHEN, W.F., PINEAULT, N., IMREN, S., MONTPETIT, B., LARGMAN, C. and HUMPHRIES, R.K. (2000). Functional cloning and characterization of a novel nonhomeodomain protein that inhibits the binding of pbx1hox complexes to DNA. J Biol Chem 275: 26172-7.

ABRAMOVICH, C., CHAVEZ, E.A., LANSDORP, P.M. and HUMPHRIES, R.K. (2002). Functional characterization of multiple domains involved in the subcellular localization of the hematopoietic pbx interacting protein (hpip). Oncogene 21: 6766-71.

ABU-SHAAR, M., RYOO, H.D. and MANN, R.S. (1999). Control of the nuclear localization of extradenticle by competing nuclear import and export signals. Genes Dev 13: 935-45.

ALLAND, L., MUHLE, R., HOU, H., JR., POTES, J., CHIN, L., SCHREIBER-AGUS, N. and DEPINHO, R.A. (1997). Role for n-cor and histone deacetylase in sin3mediated transcriptional repression. Nature 387: 49-55.

ARNOLD, H.H. and WINTER, B. (1998). Muscle differentiation: More complexity to the network of myogenic regulators. Curr Opin Genet Dev 8: 539-44.

ASAHARA, H., DUTTA, S., KAO, H.Y., EVANS, R.M. and MONTMINY, M. (1999). $\mathrm{Pbx}$-hox heterodimers recruit coactivator-corepressor complexes in an isoformspecific manner. Mol Cell Bio/19: 8219-25.

ATTISANO, L. and WRANA, J.L. (2002). Signal transduction by the tgf-beta superfamily. Science 296: 1646-7.
BAILEY, J.S., RAVE-HAREL, N., MCGILLIVRAY, S.M., COSS, D. and MELLON, P.L. (2004). Activin regulation of the follicle-stimulating hormone beta-subunit gene involves smads and the tale homeodomain proteins pbx1 and prep1. Mol Endocrino/18: 1158-70.

BERGSTROM, D.A., PENN, B.H., STRAND, A., PERRY, R.L., RUDNICKI, M.A. and TAPSCOTT, S.J. (2002). Promoter-specific regulation of myod binding and signal transduction cooperate to pattern gene expression. Mol Cel/9: 587-600.

BERKES, C.A., BERGSTROM, D.A., PENN, B.H., SEAVER, K.J., KNOEPFLER, P.S. and TAPSCOTT, S.J. (2004). Pbx marks genes for activation by myod indicating a role for a homeodomain protein in establishing myogenic potential. Mol Cel/14: 465-77.

BERRY, F.B., O'NEILL, M.A., COCA-PRADOS, M. and WALTER, M.A. (2005). Foxc1 transcriptional regulatory activity is impaired by $\mathrm{pbx} 1$ in a filamin amediated manner. Mol Cell Bio/25: 1415-24.

BERTHELSEN, J., ZAPPAVIGNA, V., MAVILIO, F. and BLASI, F. (1998). Prep1, a novel functional partner of pbx proteins. EMBO J17: 1423-33.

BERTHELSEN, J., KILSTRUP-NIELSEN, C., BLASI, F., MAVILIO, F. and ZAPPAVIGNA, V. (1999). The subcellular localization of pbx1 and exd proteins depends on nuclear import and export signals and is modulated by association with prep1 and hth. Genes Dev 13: 946-53.

BRENDOLAN, A., FERRETTI, E., SALSI, V., MOSES, K., QUAGGIN, S., BLASI, F., CLEARY, M.L. and SELLERI, L. (2005). A pbx1-dependent genetic and transcriptional network regulates spleen ontogeny. Development 132: 3113-26.

BURGLIN, T.R. (1997). Analysis of tale superclass homeobox genes (meis, pbc, knox, iroquois, tgif) reveals a novel domain conserved between plants and animals. Nucleic Acids Res 25: 4173-80.

CALVO, K.R., KNOEPFLER, P., MCGRATH, S. and KAMPS, M.P. (1999). An inhibitory switch derepressed by pbx, hox and meis/prep1 partners regulates DNA-binding by pbx1 and e2a-pbx1 and is dispensable for myeloid immortalization by e2a-pbx1. Oncogene 18: 8033-43.

CAPELLINI, T.D., DI GIACOMO, G., SALSI, V., BRENDOLAN, A., FERRETTI, E., SRIVASTAVA, D., ZAPPAVIGNA, V. and SELLERI, L. (2006). Pbx1/pbx2 requirement for distal limb patterning is mediated by the hierarchical control of hox gene spatial distribution and shh expression. Development.

CARR, A. and BIGGIN, M.D. (1999). A comparison of in vivo and in vitro DNAbinding specificities suggests a new model for homeoprotein DNA binding in Drosophila embryos. EMBO J18: 1598-608.

CHANG, C.P., SHEN, W.F., ROZENFELD, S., LAWRENCE, H.J., LARGMAN, C. and CLEARY, M.L. (1995). Pbx proteins display hexapeptide-dependent cooperative DNA binding with a subset of hox proteins. Genes Dev 9: 663-74.

DE LA SERNA, I.L., OHKAWA, Y., BERKES, C.A., BERGSTROM, D.A., DACWAG, C.S., TAPSCOTT, S.J. and IMBALZANO, A.N. (2005). Myod targets chromatin remodeling complexes to the myogenin locus prior to forming a stable DNAbound complex. Mol Cell Bio/25: 3997-4009.

DIMARTINO, J.F., SELLERI, L., TRAVER, D., FIRPO, M.T., RHEE, J., WARNKE, R., O'GORMAN, S., WEISSMAN, I.L. and CLEARY, M.L. (2001). The hox cofactor and proto-oncogene pbx1 is required for maintenance of definitive hematopoiesis in the fetal liver. Blood 98: 618-26.

DINTILHAC, A., BIHAN, R., GUERRIER, D., DESCHAMPS, S. and PELLERIN, I. (2004). A conserved non-homeodomain hoxa9 isoform interacting with cbp is co-expressed with the 'typical' hoxa9 protein during embryogenesis. Gene Expr Patterns 4: 215-22.

DUBOULE, D. (2000). Developmental genetics. A hox by any other name. Nature 403: 607, 609-10.

DUTTA, S., GANNON, M., PEERS, B., WRIGHT, C., BONNER-WEIR, S. and MONTMINY, M. (2001). Pdx:Pbx complexes are required for normal proliferation of pancreatic cells during development. Proc Nat/ Acad Sci USA 98: 106570.

FERRETTI, E., SCHULZ, H., TALARICO, D., BLASI, F. and BERTHELSEN, J. (1999). The pbx-regulating protein prep1 is present in different pbx-complexed forms in mouse. Mech Dev 83: 53-64.

GALANT, R., WALSH, C.M. and CARROLL, S.B. (2002). Hox repression of a target gene: Extradenticle-independent, additive action through multiple monomer binding sites. Development 129: 3115-26.

GAO, X., STEGEMAN, B.I., LANSER, P., KOSTER, J.G. and DESTREE, O.H. (1994). Gr transcripts are localized during early xenopus laevis embryogenesis 
and overexpression of $\mathrm{gr}$ inhibits differentiation after dexamethasone treatment. Biochem Biophys Res Commun 199: 734-41.

GEHRING, W.J., QIAN, Y.Q., BILLETER, M., FURUKUBO-TOKUNAGA, K., SCHIER, A.F., RESENDEZ-PEREZ, D., AFFOLTER, M., OTTING, G. and WUTHRICH, K. (1994). Homeodomain-DNA recognition. Cel/78: 211-23.

GONZALEZ-CRESPO, S., ABU-SHAAR, M., TORRES, M., MARTINEZ, A.C., MANN, R.S. and MORATA, G. (1998). Antagonism between extradenticle function and hedgehog signaling in the developing limb. Nature 394: 196-200.

GONZALEZ-CRESPO, S. and MORATA, G. (1996). Genetic evidence for the subdivision of the arthropod limb into coxopodite and telopodite. Development 122: $3921-8$

GOUDET, G., DELHALLE, S., BIEMAR, F., MARTIAL, J.A. and PEERS, B. (1999). Functional and cooperative interactions between the homeodomain pdx1, pbx and prep1 factors on the somatostatin promoter. J Biol Chem 274: 4067-73.

GREER, J.M., PUETZ, J., THOMAS, K.R. and CAPECCHI, M.R. (2000). Maintenance of functional equivalence during paralogous hox gene evolution. Nature 403: $661-5$

HEINZEL, T., LAVINSKY, R.M., MULLEN, T.M., SODERSTROM, M., LAHERTY, C.D., TORCHIA, J., YANG, W.M., BRARD, G., NGO, S.D., DAVIE, J.R. et al. (1997). A complex containing $\mathrm{n}$-cor, msin3 and histone deacetylase mediates transcriptional repression. Nature 387: 43-8.

HIRSCH, J.A. and AGGARWAL, A.K. (1995). Structure of the even-skipped homeodomain complexed to at-rich DNA: New perspectives on homeodomain specificity. EMBO J14: 6280-91.

HUANG, H., PALIOURAS, M., RAMBALDI, I., LASKO, P. and FEATHERSTONE, M. (2003). Nonmuscle myosin promotes cytoplasmic localization of pbx. MO/ Cell Bio/23: 3636-45.

HUANG, H., RASTEGAR, M., BODNER, C., GOH, S.L., RAMBALDI, I. and FEATHERSTONE, M. (2005). Meis c termini harbor transcriptional activation domains that respond to cell signaling. J Biol Chem 280: 10119-27.

IN DER RIEDEN, P.M., MAINGUY, G., WOLTERING, J.M. and DURSTON, A.J. (2004). Homeodomain to hexapeptide or pbc-interaction-domain distance: Size apparently matters. Trends Genet 20: 76-9.

JACOBSON, E.M., LI, P., LEON-DEL-RIO, A., ROSENFELD, M.G. and AGGARWAL, A.K. (1997). Structure of pit-1 pou domain bound to DNA as a dimer: Unexpected arrangement and flexibility. Genes Dev 11: 198-212.

KAMPS, M.P., MURRE, C., SUN, X.H. and BALTIMORE, D. (1990). A new homeobox gene contributes the DNA binding domain of the $t(1 ; 19)$ translocation protein in pre-b all. Ce//60: 547-55.

KIDSON, S.H., KUME, T., DENG, K., WINFREY, V. and HOGAN, B.L. (1999). The forkhead/winged-helix gene, $\mathrm{mf} 1$, is necessary for the normal development of the cornea and formation of the anterior chamber in the mouse eye. Dev Biol 211: 306-22.

KILSTRUP-NIELSEN, C., ALESSIO, M. and ZAPPAVIGNA, V. (2003). Pbx1 nuclear export is regulated independently of pbx-meinox interaction by pka phosphorylation of the pbc-b domain. EMBO J22: 89-99.

KNOEPFLER, P.S., BERGSTROM, D.A., UETSUKI, T., DAC-KORYTKO, I., SUN, Y.H., WRIGHT, W.E., TAPSCOTT, S.J. and KAMPS, M.P. (1999). A conserved motif $n$-terminal to the DNA-binding domains of myogenic bhlh transcription factors mediates cooperative DNA binding with pbx-meis $1 /$ prep 1. Nucleic Acids Res 27: 3752-61.

KOMUVES, L.G., SHEN, W.F., KWONG, A., STELNICKI, E., ROZENFELD, S., ODA, Y., BLINK, A., KRISHNAN, K., LAU, B., MAURO, T. et al. (2000). Changes in hoxb6 homeodomain protein structure and localization during human epidermal development and differentiation. Dev Dyn 218: 636-47.

KUME, T., DENG, K. and HOGAN, B.L. (2000). Murine forkhead/winged helix genes foxc1 (mf1) and foxc2 (mfh1) are required for the early organogenesis of the kidney and urinary tract. Development 127: 1387-95.

KUME, T., JIANG, H., TOPCZEWSKA, J.M. and HOGAN, B.L. (2001). The murine winged helix transcription factors, foxc1 and foxc2, are both required for cardiovascular development and somitogenesis. Genes Dev 15: 2470-82.

LAURENT, A., BIHAN, R., DESCHAMPS, S., GUERRIER, D., DUPE, V., OMILLI, F., BUREL, A. and PELLERIN, I. (2007). Identification of a new type of pbx1 partner that contains zinc finger motifs and inhibits the binding of hoxa9-pbx1 to DNA. Mech Dev.124: 364-376.

LEONARD, J., PEERS, B., JOHNSON, T., FERRERI, K., LEE, S. and MONTMINY,
M.R. (1993). Characterization of somatostatin transactivating factor-1, a novel homeobox factor that stimulates somatostatin expression in pancreatic islet cells. Mol Endocrino/7: 1275-83.

LI, X., NIE, S., CHANG, C., QIU, T. and CAO, X. (2006). Smads oppose hox transcriptional activities. Exp Cel/ Res 312: 854-64.

LIU, Y., MACDONALD, R.J. and SWIFT, G.H. (2001). DNA binding and transcriptional activation by a pdx1.Pbx1b.Meis2b trimer and cooperation with a pancreas-specific basic helix-loop-helix complex. J Biol Chem 276: 17985-93.

MAHAFFEY, J.W. (2005). Assisting hox proteins in controlling body form: Are there new lessons from flies (and mammals)? Curr Opin Genet Dev 15: 422-9.

MANAVATHI, B., ACCONCIA, F., RAYALA, S.K. and KUMAR, R. (2006). An inherent role of microtubule network in the action of nuclear receptor. Proc Nat/ Acad Sci USA 103: 15981-6.

MANGELSDORF, D.J., THUMMEL, C., BEATO, M., HERRLICH, P., SCHUTZ, G., UMESONO, K., BLUMBERG, B., KASTNER, P., MARK, M., CHAMBON, P. et al. (1995). The nuclear receptor superfamily: The second decade. Ce//83: 835-

MANLEY, N.R., SELLERI, L., BRENDOLAN, A., GORDON, J. and CLEARY, M.L. (2004). Abnormalities of caudal pharyngeal pouch development in pbx1 knockout mice mimic loss of hox3 paralogs. Dev Bio/276: 301-12.

MANN, R.S. and CHAN, S.K. (1996). Extra specificity from extradenticle: The partnership between hox and pbx/exd homeodomain proteins. Trends Genet 12: 258-62.

MANN, R.S. and AFFOLTER, M. (1998). Hox proteins meet more partners. Curr Opin Genet Dev 8: 423-9.

MARTENS, J.A. and WINSTON, F. (2003). Recent advances in understanding chromatin remodeling by swi/snf complexes. Curr Opin Genet Dev 13: 136-42.

MEAD, P.E., BRIVANLOU, I.H., KELLEY, C.M. and ZON, L.I. (1996). Bmp-4responsive regulation of dorsal-ventral patterning by the homeobox protein mix.1. Nature 382: 357-60.

MERABET, S., KAMBRIS, Z., CAPOVILLA, M., BERENGER, H., PRADEL, J. and GRABA, Y. (2003). The hexapeptide and linker regions of the abda hox protein regulate its activating and repressive functions. Dev Ce//4: 761-8.

MILECH, N., KEES, U.R. and WATT, P.M. (2001). Novel alternative pbx3 isoforms in leukemia cells with distinct interaction specificities. Genes Chromosomes Cancer 32: 275-80.

MOENS, C.B. and SELLERI, L. (2006). Hox cofactors in vertebrate development. Dev Bio/291: 193-206.

MONICA, K., GALILI, N., NOURSE, J., SALTMAN, D. and CLEARY, M.L. (1991). $\mathrm{Pbx} 2$ and $\mathrm{pbx} 3$, new homeobox genes with extensive homology to the human proto-oncogene pbx1. Mol Cel/ Biol11: 6149-57.

NAGY, L., KAO, H.Y., CHAKRAVARTI, D., LIN, R.J., HASSIG, C.A., AYER, D.E., SCHREIBER, S.L. and EVANS, R.M. (1997). Nuclear receptor repression mediated by a complex containing smrt, msin3a and histone deacetylase. Cell 89: 373-80.

NEUTEBOOM, S.T. and MURRE, C. (1997). Pbx raises the DNA binding specificity but not the selectivity of antennapedia hox proteins. Mo/ Cel/ Bio/17: 4696-706.

NORO, B., CULI, J., MCKAY, D.J., ZHANG, W. and MANN, R.S. (2006). Distinct functions of homeodomain-containing and homeodomain-less isoforms encoded by homothorax. Genes Dev 20: 1636-50.

NOURSE, J., MELLENTIN, J.D., GALILI, N., WILKINSON, J., STANBRIDGE, E., SMITH, S.D. and CLEARY, M.L. (1990). Chromosomal translocation t $(1 ; 19)$ results in synthesis of a homeobox fusion mrna that codes for a potential chimeric transcription factor. Cel/60: 535-45.

PEERS, B., SHARMA, S., JOHNSON, T., KAMPS, M. and MONTMINY, M. (1995) The pancreatic islet factor stf-1 binds cooperatively with pbx to a regulatory element in the somatostatin promoter: Importance of the fpwmk motif and of the homeodomain. Mol Cel/ Biol15: 7091-7.

PELTENBURG, L.T. and MURRE, C. (1996). Engrailed and hox homeodomain proteins contain a related pbx interaction motif that recognizes a common structure present in pbx. EMBO J15: 3385-93.

POELLINGER, L. and ROEDER, R.G. (1989). Octamer transcription factors 1 and 2 each bind to two different functional elements in the immunoglobulin heavychain promoter. $\mathrm{Mo} / \mathrm{Ce} / \mathrm{Bio} / 9$ : 747-56.

POPPERL, H., RIKHOF, H., CHANG, H., HAFFTER, P., KIMMEL, C.B. and 
MOENS, C.B. (2000). Lazarus is a novel pbx gene that globally mediates hox gene function in zebrafish. Mo/ Ce//6: 255-67.

RAUSKOLB, C., SMITH, K.M., PEIFER, M. and WIESCHAUS, E. (1995). Extradenticle determines segmental identities throughout Drosophila development. Development 121: 3663-73.

RHEE, J.W., ARATA, A., SELLERI, L., JACOBS, Y., ARATA, S., ONIMARU, H. and CLEARY, M.L. (2004). Pbx3 deficiency results in central hypoventilation. $A m J$ Pathol 165: 1343-50.

RIECKHOF, G.E., CASARES, F., RYOO, H.D., ABU-SHAAR, M. and MANN, R.S. (1997). Nuclear translocation of extradenticle requires homothorax, which encodes an extradenticle-related homeodomain protein. Ce//91: 171-83.

SALEH, M., RAMBALDI, I., YANG, X.J. and FEATHERSTONE, M.S. (2000). Cell signaling switches hox-pbx complexes from repressors to activators of transcription mediated by histone deacetylases and histone acetyltransferases. Mol Cell Biol20: 8623-33.

SALMA, N., XIAO, H., MUELLER, E. and IMBALZANO, A.N. (2004). Temporal recruitment of transcription factors and swi/snf chromatin-remodeling enzymes during adipogenic induction of the peroxisome proliferator-activated receptor gamma nuclear hormone receptor. Mol Cel/ Bio/24: 4651-63.

SCHNABEL, C.A., SELLERI, L., JACOBS, Y., WARNKE, R. and CLEARY, M.L. (2001). Expression of pbx1b during mammalian organogenesis. Mech Dev100: 131-5.

SCHNABEL, C.A., GODIN, R.E. and CLEARY, M.L. (2003). Pbx1 regulates nephrogenesis and ureteric branching in the developing kidney. Dev Bio/254: 262-76.

SELLERI, L., DEPEW, M.J., JACOBS, Y., CHANDA, S.K., TSANG, K.Y., CHEAH, K.S., RUBENSTEIN, J.L., O'GORMAN, S. and CLEARY, M.L. (2001). Requirement for pbx1 in skeletal patterning and programming chondrocyte proliferation and differentiation. Development 128: 3543-57.

SELLERI, L., DIMARTINO, J., VAN DEURSEN, J., BRENDOLAN, A., SANYAL, M., BOON, E., CAPELLINI, T., SMITH, K.S., RHEE, J., POPPERL, H. et al. (2004). The tale homeodomain protein pbx2 is not essential for development and longterm survival. Mol Cel/ Biol24: 5324-31.

SHANMUGAM, K., GREEN, N.C., RAMBALDI, I., SARAGOVI, H.U. and FEATHERSTONE, M.S. (1999). Pbx and meis as non-DNA-binding partners in trimeric complexes with hox proteins. Mol Cel/ Biol19: 7577-88.

SHEN, W.F., ROZENFELD, S., KWONG, A., KOM VES, L.G., LAWRENCE, H.J. and LARGMAN, C. (1999). Hoxa9 forms triple complexes with pbx2 and meis1 in myeloid cells. Mol Cell Bio/19: 3051-61.

SHEN, W.F., KRISHNAN, K., LAWRENCE, H.J. and LARGMAN, C. (2001). The hox homeodomain proteins block cbp histone acetyltransferase activity. Mol Cell Bio/21: 7509-22.

SIF, S. (2004). Atp-dependent nucleosome remodeling complexes: Enzymes tailored to deal with chromatin. J Cel/ Biochem 91: 1087-98.

SOUTOGLOU, E. and TALIANIDIS, I. (2002). Coordination of pic assembly and chromatin remodeling during differentiation-induced gene activation. Science 295: $1901-4$

SPILIANAKIS, C., KRETSOVALI, A., AGALIOTI, T., MAKATOUNAKIS, T., THANOS, D. and PAPAMATHEAKIS, J. (2003). Ciita regulates transcription onset viaser5phosphorylation of rna pol ii. EMBO J22: 5125-36.

SUBRAMANIAM, N., CAIRNS, W. and OKRET, S. (1998). Glucocorticoids repress transcription from a negative glucocorticoid response element recognized by two homeodomain-containing proteins, pbx and oct-1. J Biol Chem273: 2356774.

SUBRAMANIAM, N., CAMPION, J., RAFTER, I. and OKRET, S. (2003). Cross-talk between glucocorticoid and retinoic acid signals involving glucocorticoid receptor interaction with the homoeodomain protein pbx1. Biochem J370: 1087-95.

SUH, E., CHEN, L., TAYLOR, J. and TRABER, P.G. (1994). A homeodomain protein related to caudal regulates intestine-specific gene transcription. Mo/ Ce/l Biol 14: 7340-51.

SWIFT, G.H., LIU, Y., ROSE, S.D., BISCHOF, L.J., STEELMAN, S., BUCHBERG, A.M., WRIGHT, C.V. and MACDONALD, R.J. (1998). An endocrine-exocrine switch in the activity of the pancreatic homeodomain protein $\mathrm{pdx} 1$ through formation of a trimeric complex with pbx1b and mrg1 (meis2). Mol Cell Bio/18: 5109-20.

TAKACS-VELLAI, K., VELLAI, T., CHEN, E.B., ZHANG, Y., GUERRY, F., STERN, M.J. and MULLER, F. (2007). Transcriptional control of notch signaling by a hox and a pbx/exd protein during vulval development in c. Elegans. Dev Bio/302: 661-9.

WAGNER, K., MINCHEVA, A., KORN, B., LICHTER, P. and POPPERL, H. (2001). $\mathrm{Pbx} 4$, a new pbx family member on mouse chromosome 8 , is expressed during spermatogenesis. Mech Dev103: 127-31.

WALTER, J., DEVER, C.A. and BIGGIN, M.D. (1994). Two homeo domain proteins bind with similar specificity to a wide range of DNA sites in Drosophila embryos. Genes Dev 8: 1678-92.

WAN, M., SHI, X., FENG, X. and CAO, X. (2001). Transcriptional mechanisms of bone morphogenetic protein-induced osteoprotegrin gene expression. J Biol Chem 276: 10119-25.

WANG, J.M., PREFONTAINE, G.G., LEMIEUX, M.E., POPE, L., AKIMENKO, M.A. and HACHE, R.J. (1999). Developmental effects of ectopic expression of the glucocorticoid receptor DNA binding domain are alleviated by an amino acid substitution that interferes with homeodomain binding. Mol Ce// Bio/19: 710622.

WANG, Y., YIN, L. and HILLGARTNER, F.B. (2001). The homeodomain proteins $\mathrm{pbx}$ and meis 1 are accessory factors that enhance thyroid hormone regulation of the malic enzyme gene in hepatocytes. J Biol Chem 276: 23838-48.

WASKIEWICZ, A.J., RIKHOF, H.A., HERNANDEZ, R.E. and MOENS, C.B. (2001). Zebrafish meis functions to stabilize pbx proteins and regulate hindbrain patterning. Development 128: 4139-51.

WASKIEWICZ, A.J., RIKHOF, H.A. and MOENS, C.B. (2002). Eliminating zebrafish pbx proteins reveals a hindbrain ground state. Dev Cel/3: 723-33.

WILLIAMS, T.M., WILLIAMS, M.E. and INNIS, J.W. (2005). Range of hox/tale superclass associations and protein domain requirements for hoxa13:Meis interaction. Dev Bio/277: 457-71.

WILSON, D., SHENG, G., LECUIT, T., DOSTATNI, N. and DESPLAN, C. (1993). Cooperative dimerization of paired class homeo domains on DNA. Genes Dev 7: 2120-34.

WINNIER, G.E., KUME, T., DENG, K., ROGERS, R., BUNDY, J., RAINES, C., WALTER, M.A., HOGAN, B.L. and CONWAY, S.J. (1999). Roles for the winged helix transcription factors $\mathrm{mf} 1$ and $\mathrm{mfh} 1$ in cardiovascular development revealed by nonallelic noncomplementation of null alleles. Dev Bio/213: 418-31.

ZHAO, Y. and POTTER, S.S. (2001). Functional specificity of the hoxa13 homeobox. Development 128: 3197-207. 


\section{Related, previously published Int. J. Dev. Biol. articles}

See our Special Issue Ear Development edited by Fernando Giraldez and Bernd Fritzsch at:

http://www.ijdb.ehu.es/web/contents.php?vol=51\&issue=6-7

Hox and ParaHox genes in Nemertodermatida, a basal bilaterian clade

Eva Jiménez-Guri, Jordi Paps, Jordi García-Fernández and Emili Saló

Int. J. Dev. Biol. (2006) 50: 675-679

Pulling forces acting on Hox gene clusters cause expression collinearity

Spyros Papageorgiou

Int. J. Dev. Biol. (2006) 50: 301-308

2006 ISI **Impact Factor $=3.577^{* *}$

Head-tail patterning of the vertebrate embryo: one, two or many unresolved problems?

Claudio D. Stern, Jeroen Charité, Jacqueline Deschamps, Denis Duboule, Anthony J. Durston, Marie Kmita, Jean-

François Nicolas, Isabel Palmeirim, Jim C. Smith and Lewis Wolpert

Int. J. Dev. Biol. (2006) 50: 3-15

PBX1 intracellular localization is independent of MEIS1 in epithelial cells of the developing female genital tract Agnès Dintilhac, Réjane Bihan, Daniel Guerrier, Stéphane Deschamps, Héloise Bougerie, Tanguy Watrin, Georgette Bonnec and Isabelle Pellerin

Int. J. Dev. Biol. (2005) 49: 851-858

$\mathrm{Pbx}$ genes are required in Xenopus lens development Richard Morgan, Jastinder Sohal, Mita Paleja and Ruth Pettengell

Int. J. Dev. Biol. (2004) 48: 623-627

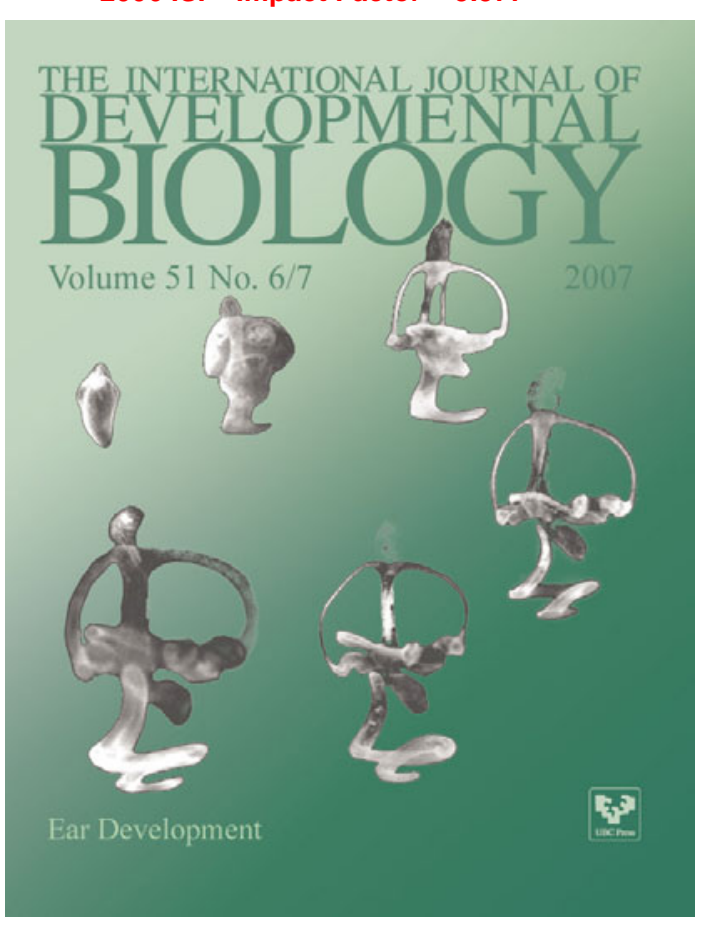

